Article

\title{
Service Perceptions in Fitness Centers: IPA Approach by Gender and Age
}

\author{
Jairo León-Quismondo ${ }^{1, * \mathbb{C}}$, Jorge García-Unanue ${ }^{2}\left(\mathbb{D}\right.$ and Pablo Burillo ${ }^{1}$ \\ 1 Faculty of Sport Sciences, Universidad Europea de Madrid, 28670 Madrid, Spain; \\ pablo.burillo@universidadeuropea.es \\ 2 IGOID Research Group, Department of Physical Activity and Sport Sciences, \\ University of Castilla-La Mancha, 45071 Toledo, Spain; jorge.garciaunanue@uclm.es \\ * Correspondence: jairo.leon@universidadeuropea.es; Tel.: +34-912-113-505
}

Received: 19 March 2020; Accepted: 16 April 2020; Published: 21 April 2020

\begin{abstract}
Background: The number of fitness practitioners has increased in the last decades. A deeper understanding of user perceptions is required for better service design. Methods: An importance-performance analysis (IPA) and correlational analysis were performed on a sample of 414 members (173 women and 241 men) with a mean age of 32.33 years $(\mathrm{SD}=11.50)$ and recruited from 25 fitness centers of Community of Madrid, Spain. Results: The results show that women's levels of importance and performance are higher than men in most of the service attributes. Women also correlate with a higher priority than men in core elements of the service, such as the variety and number of activities, personal training and fitness service quality. Female members feel more attracted by services like swimming pools and other peripheral services, like a welcome pack and medical or physiotherapist service. According to age, older members feel less satisfied than young users with the cleanliness of activity spaces and with the safety of lockers. Conclusions: Differences in perceptions by age and gender were identified among members of fitness centers. These results should be considered by private and public organizations to provide the best practices and tailored services for engaging more people in physical activity.
\end{abstract}

Keywords: fitness centers; importance-performance analysis (IPA); correlation; gender; age

\section{Introduction}

In recent years, global increasing interest in physical activity and sports practice has happened. Consequently, the number of services related to well-being, physical activity or sports has grown, aiming to respond to such demand [1]. Thus, physical activity participants have changed from a situation in which they had to adapt to the offer of sports services to the opposite one. Nowadays, physical activity offer is much diverse and is more tailored to the user's needs [2]. In this regard, fitness centers are a reference of health services, helping to encourage people to engage in physical activity services [3-5]. The open and dynamic nature of the fitness industry [6] means that it is continually evolving, adapting to every situation and context. Therefore, users have more possibilities to compare services in order to choose the one that best meets their needs. Hence, sports services providers should consider customers as expert [7].

The research field has attracted attention in the last decades, including those exploring service quality [8]. Perceived quality [9-12], satisfaction [13-16] and loyalty [17-19] are some examples of the research lines related to the fitness industry in last years. All this information is considered essential for a better understanding of consumers, for offering highly professional service and for better practices in fitness centers. However, an apparent gap in the literature regarding practical applications of tools in the fitness industry is identified. 
The relationship between research and practices is progressively becoming closer. A detailed analysis of the provided service contributes to make managerial actions more precise, by taking into consideration some variables, such as demographic factors $[20,21]$. Thus, importance-performance analysis (IPA), developed by Martilla and James [22], is a useful tool for any kind of organization. It has recently been applied in health clubs, fitness, well-being services [9,12,23-29]. IPA is based on respondents' judgments on the importance and performance of different service attributes. This way, it allows differentiating the strengths and the weakens. Following Ábalo, Varela, and Rial [30], according to the level of importance and performance, every attribute can be classified into concentrate here, keep up the good work, possible overkill or low priority (Figure 1). This makes possible to understand the consumer priorities, perceptions and, subsequently, the more urgent areas to attend to.

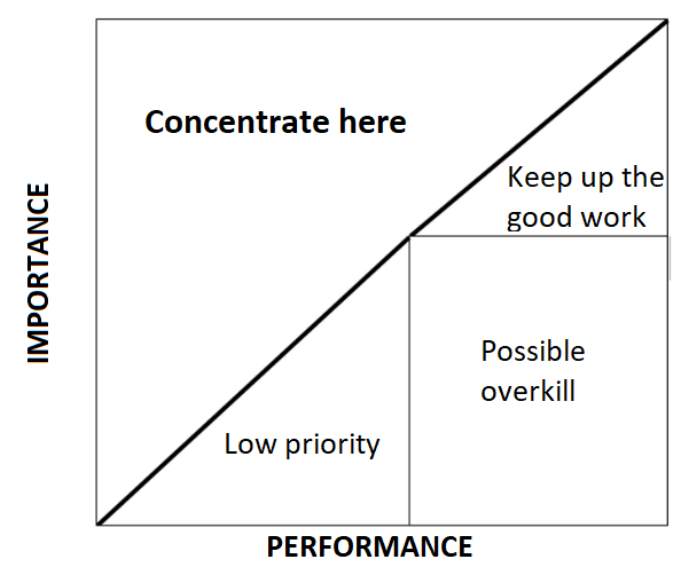

Figure 1. Importance-performance analysis (IPA) matrix.

In IPA, the discrepancy between the level of performance and importance is also measured. A negative discrepancy is related to levels of dissatisfaction, whereas a positive one leads to satisfaction. In the IPA matrix, the discrepancy line is represented as a crossing line, also understood as iso-rating or iso-priority line [31]. Thus, larger positive discrepancies lead to greater satisfaction, while larger negative discrepancies cause greater dissatisfaction.

The purpose of this work is to discover the differences in perceptions and priorities regarding gender and age. Even though some studies on physical activity participation and sports performance have been completed, the knowledge of physical activity participation motives and perceptions-specifically in fitness centers-should be examined. In this way, public and private sports organizations could promote politics highly related to customer needs, according to their gender and age.

Thus, the aim of this paper is to explore the perceptions of fitness services quality by gender and age, as well as to examine the correlation of different service attributes with these two variables.

\section{Materials and Methods}

\subsection{Design and Participants}

A correlational study was conducted with a convenience sample of 414 members (Figure 2) recruited from 25 privately managed fitness centers, including 8 low-cost centers $(n=148$ members), 15 mid-market centers ( $n=212$ members), and 2 premium centers $(n=54$ members). Participants were aged between 18 and $77(\mathrm{M}=32.33$ years; $\mathrm{SD}=11.50)$ (Table 1$)$. Most of the participants had belonged to the center for longer than 12 consecutive months $(56.30 \%)$, had a university certification $(55.60 \%)$, and they were closer than 15 minutes to the fitness center $(84.10 \%)$. Peak attendance time was on Mondays between 6 p.m. and 10 p.m.

All the participants should belong to privately managed fitness centers located in the Community of Madrid, Spain, not oriented to a simple sport modality or martial arts, with at least one weight 
room with machines and free weight, and one or more rooms for group classes. Although it was not a mandatory requirement, 11 fitness centers had a swimming pool.

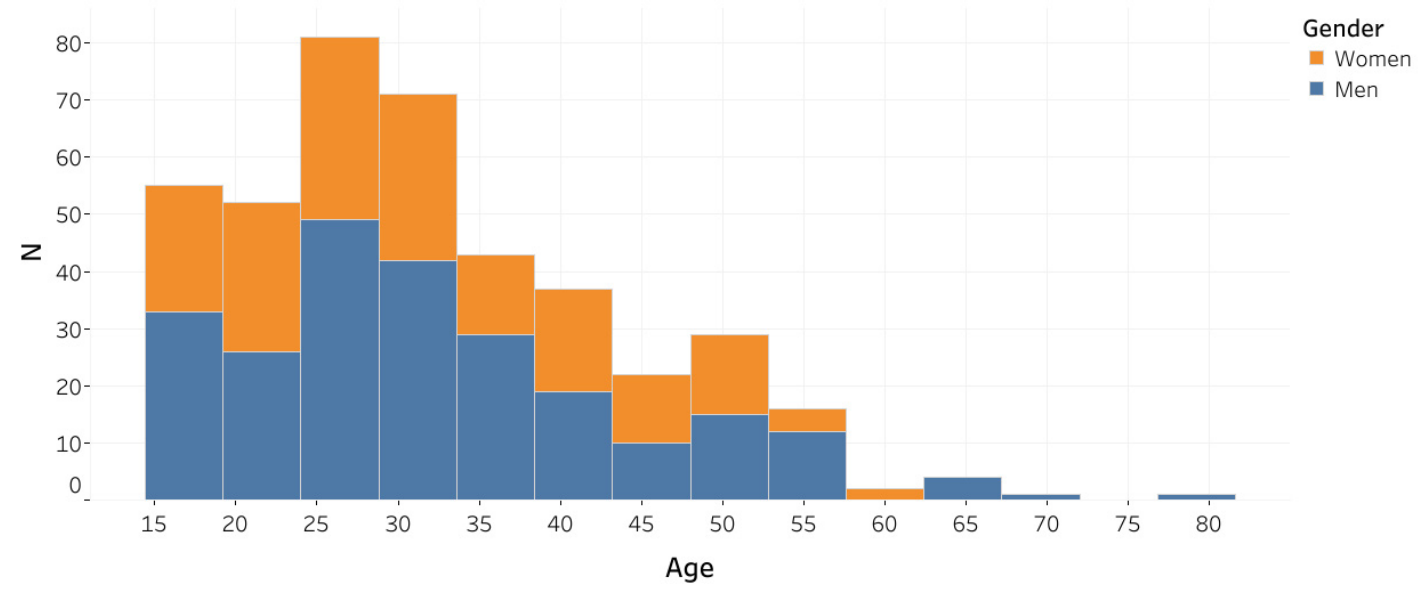

Figure 2. Histogram of age by gender.

Table 1. Mean age by gender.

\begin{tabular}{cccc}
\hline Gender & $\boldsymbol{N}$ & Age in Years & SD \\
\hline Women & 173 & 31.92 & 11.00 \\
Men & 241 & 31.62 & 11.85 \\
\hline Annotations: $N$ & $=$ frequency; SD = Standard deviation.
\end{tabular}

\subsection{Instrument}

A validated questionnaire based on importance-performance analysis (IPA) [22] was designed. The questionnaire validation was performed in Spain. An initial literature review allowed to determine the most useful information to collect [13,15,24,32-34]. Next, the number of initial items was reduced and, later, reviewed by a panel of experts (four $\mathrm{PhD}$ university professors with a research experience of more than five years and two managers of fitness centers with more than five years of experience). The panel of experts offered their individual opinion about the adequacy of each item. Finally, an agreement was reached. The final version comprises 29 items for the importance scale $(\alpha=0.873)$ and the same 29 elements for the performance scale $(\alpha=0.895)$.

Every participant valued on a 5-point Likert scale the level of importance of the 29 attributes ( 1 = not important; 5 = very important), as well as the level of performance of the same 29 attributes (1 = low performance; 5 = high performance).

\subsection{Procedure}

Questionnaires were distributed personally by the same researcher, between June of 2016 and November 2017. This extensive period of data collection allowed a wide variety of participants to be covered, with diverse characteristics. The contact with participants was either at the moment of arriving or leaving the fitness center. All of them were informed about the research objectives and they accepted to participate voluntarily.

\subsection{Data Analysis}

The analysis was performed with IBM SPSS 23.0 Statistics software (IBM Inc., Chicago, IL, USA), setting the critical level of significance at $p<0.05$. The descriptive data are described as mean and standard deviation. Kolmogorov Smirnoff analysis showed a non-normal behavior of variables. Therefore, non-parametric tests were performed. A Wilcoxon test was used for inference analysis in 
comparisons between importance and performance, while a Spearman test was applied for correlational analyses. The sociodemographic variables considered were gender and age. Regarding the IPA model, the data interpretation was based on Ábalo et al. [30].

\section{Results}

\subsection{Gender}

The IPA analysis contrast between men and women is displayed in Table 2. Overall results show that women's levels of importance and performance are higher than the men's. However, given the average level of discrepancy, the perception of female members is related to higher levels of dissatisfaction $($ women $=-0.60$; men $=-0.52$ ).

Table 2. IPA results according to gender.

\begin{tabular}{|c|c|c|c|c|c|c|c|c|c|c|c|}
\hline & \multirow[t]{2}{*}{ Items } & \multicolumn{5}{|c|}{ Women } & \multicolumn{5}{|c|}{ Men } \\
\hline & & $\mathbf{I}$ & SD & $\mathbf{P}$ & SD & $\mathbf{D}$ & $\mathbf{I}$ & SD & $\mathbf{P}$ & SD & $\mathbf{D}$ \\
\hline 1 & Accessibility: closeness to member homes & 4.83 & 0.53 & 4.23 & 1.08 & $-0.60 * *$ & 4.75 & 0.67 & 4.25 & 0.91 & $-0.50 * *$ \\
\hline 3 & Hours and days of operation & 4.72 & 0.74 & 4.15 & 1.21 & $-0.57 * *$ & 4.62 & 0.76 & 4.23 & 0.97 & $-0.42 * *$ \\
\hline 4 & Kindness and treat from staff & 4.64 & 0.64 & 4.14 & 1.03 & $-0.50^{* *}$ & 4.14 & 1.00 & 4.13 & 0.87 & $-0.01 * *$ \\
\hline 5 & Achievement of outcomes from instructors & 4.28 & 0.88 & 3.81 & 1.04 & $-0.47^{* *}$ & 4.09 & 1.00 & 3.56 & 0.96 & $-0.53 * *$ \\
\hline 8 & Large activity spaces & 4.51 & 0.87 & 3.81 & 0.98 & $-0.70 * *$ & 4.35 & 0.94 & 3.79 & 0.98 & $-0.56^{* *}$ \\
\hline 9 & Level of maintenance of activity spaces & 4.71 & 0.53 & 4.09 & 0.97 & $-0.62 * *$ & 4.56 & 0.81 & 3.92 & 1.00 & $-0.64^{* *}$ \\
\hline 10 & Hygiene and cleanliness of activity spaces & 4.75 & 0.57 & 4.15 & 0.95 & $-0.60 * *$ & 4.66 & 0.77 & 4.13 & 0.93 & $-0.53^{* *}$ \\
\hline 11 & Ventilation (temperature) of activity spaces & 4.56 & 0.80 & 3.84 & 1.07 & $-0.72 * *$ & 4.47 & 0.85 & 3.76 & 1.09 & $-0.71^{* *}$ \\
\hline 12 & Number of pieces of equipment & 4.58 & 0.75 & 3.85 & 1.00 & $-0.73 * *$ & 4.46 & 0.94 & 3.69 & 1.00 & $-0.77^{* *}$ \\
\hline 13 & Level of maintenance of equipment/material & 4.67 & 0.60 & 4.03 & 0.93 & $-0.64 * *$ & 4.52 & 0.79 & 3.86 & 1.02 & $-0.66^{* *}$ \\
\hline 18 & Spacious and safe lockers & 4.51 & 0.83 & 3.98 & 0.98 & $-0.53 * *$ & 4.40 & 0.90 & 3.65 & 1.08 & $-0.75^{* *}$ \\
\hline 19 & Hair dryer in restrooms & 4.25 & 1.03 & 3.72 & 1.15 & $-0.53 * *$ & 3.85 & 1.10 & 3.50 & 1.12 & $-0.35^{* *}$ \\
\hline 20 & Variety and number of activities & 4.61 & 0.70 & 4.04 & 0.92 & $-0.57 * *$ & 4.11 & 0.95 & 3.80 & 0.94 & $-0.31 * *$ \\
\hline 21 & Fitness service quality & 4.56 & 0.70 & 4.00 & 0.93 & $-0.56^{* *}$ & 4.22 & 0.94 & 3.78 & 0.90 & $-0.44^{* *}$ \\
\hline 22 & Personal training quality & 4.41 & 0.97 & 3.72 & 1.09 & $-0.69 * *$ & 4.05 & 1.02 & 3.59 & 0.97 & $-0.46^{* *}$ \\
\hline 23 & Lending towels service & 3.69 & 1.27 & 2.93 & 1.05 & $-0.76^{* *}$ & 3.54 & 1.18 & 2.99 & 1.08 & -0.55 * \\
\hline 24 & Personal hygiene products in restrooms & 3.76 & 1.27 & 2.90 & 1.06 & $-0.86^{* *}$ & 3.67 & 1.15 & 3.11 & 1.17 & $-0.56^{* *}$ \\
\hline 25 & Medical/physiotherapist services & 4.21 & 1.05 & 3.44 & 0.94 & $-0.77^{* *}$ & 3.91 & 1.13 & 3.12 & 1.15 & $-0.79 * *$ \\
\hline 26 & Cafeteria/restaurant & 3.63 & 1.31 & 3.33 & 1.21 & -0.30 & 3.51 & 1.16 & 3.30 & 1.07 & -0.21 * \\
\hline 27 & Wi-Fi & 4.17 & 1.13 & 3.37 & 1.32 & $-0.80 * *$ & 3.93 & 1.29 & 3.23 & 1.40 & $-0.70^{* *}$ \\
\hline 28 & Client profile in the fitness center & 4.06 & 0.94 & 3.68 & 0.90 & $-0.38^{* *}$ & 3.97 & 0.97 & 3.72 & 0.82 & $-0.25^{* *}$ \\
\hline 29 & Fitness center as social meeting point & 3.60 & 1.20 & 3.60 & 0.93 & 0.00 & 3.52 & 1.25 & 3.65 & 0.91 & +0.13 \\
\hline
\end{tabular}

Annotations: $\mathrm{I}=$ importance; $\mathrm{P}=$ performance; $\mathrm{D}=$ discrepancy; $\mathrm{SD}=$ standard deviation; ${ }^{*} p<0.05 ;{ }^{* *} p<0.01$.

Figure 3 shows the IPA matrix by gender, presenting the aggregate importance and performance values. It can be observed that most of the analyzed items are in the concentrate here area, above the discrepancy line. This means all these elements are related to levels of dissatisfaction. A possible waste of resources is present in item 16 for women, spacious and hygienic restrooms, and item 29 for men, fitness center as a social meeting point.

Table 3 illustrates the correlation between gender and both, importance and performance values. Statistically significantly higher levels in both scales, importance and performance, positively correlate with female members.

\subsection{Age}

The same analysis was performed by age. Three groups were considered: 18 to 29 years old $(n=202), 30$ to 49 years old $(n=168)$, and 50 to 77 years old $(n=44)$. Figure 4 shows the IPA results for 
each group. The data distribution is more similar between the young and middle-age groups, but some contrast is represented in the older group.

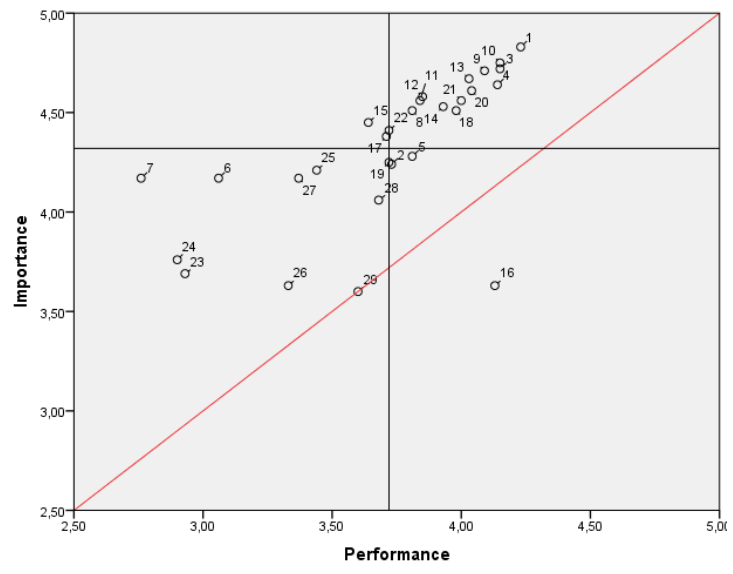

(a)

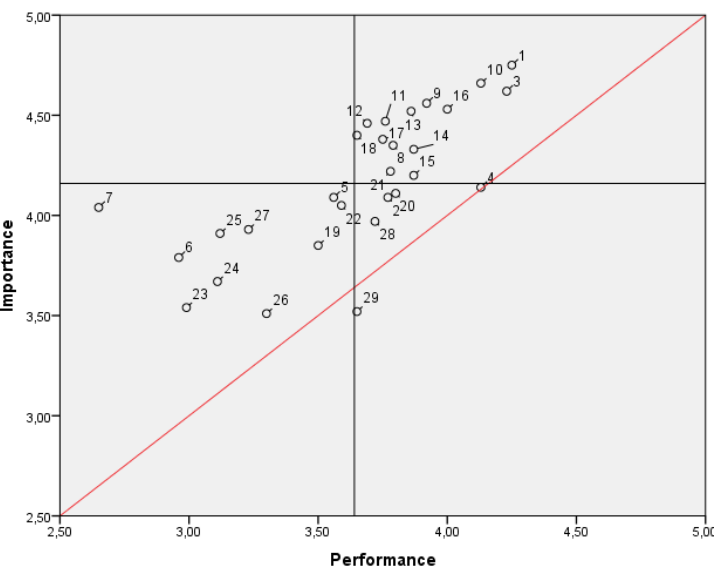

(b)

Figure 3. IPA matrix comparison by gender: (a) women; (b) men.

Table 3. Gender correlation with importance and performance scores.

\begin{tabular}{clcc}
\hline & \multicolumn{1}{c}{ Items } & Importance & Performance \\
\cline { 3 - 4 } & & Correlation with Gender & Correlation with Gender \\
\hline 1 & Accessibility: closeness to member homes & 0.056 & 0.036 \\
2 & Fees & 0.069 & -0.001 \\
3 & Hours and days of operation & $0.104^{*}$ & 0.022 \\
4 & Kindness and treat from staff & $0.098^{*}$ & 0.043 \\
5 & Achievement of outcomes from instructors & 0.089 & $0.140^{* *}$ \\
6 & Gifts for attracting new customers & $0.160^{* *}$ & 0.041 \\
7 & Gifts for rewarding current customers & 0.029 & 0.048 \\
8 & Large activity spaces & $0.097^{*}$ & 0.015 \\
9 & Level of maintenance of activity spaces & 0.067 & 0.090 \\
10 & Hygiene and cleanliness of activity spaces & 0.028 & 0.020 \\
11 & Ventilation (temperature) of activity spaces & 0.056 & 0.038 \\
12 & Number of pieces of equipment & 0.086 & 0.082 \\
13 & Level of maintenance of equipment/material & 0.087 & 0.090 \\
14 & Swimming pool/SPA (general) & $0.109 *$ & 0.054 \\
15 & Swimming pool temperature & $0.145^{* *}$ & -0.092 \\
16 & Spacious and hygienic restrooms & 0.089 & 0.064 \\
17 & Shower quality & 0.012 & -0.023 \\
18 & Spacious and safe lockers & 0.064 & $0.153^{* *}$ \\
19 & Hair dryer in restrooms & $0.191 * *$ & $0.110^{*}$ \\
20 & Variety and number of activities & $0.292^{* *}$ & $0.148^{* *}$ \\
21 & Fitness service quality & $0.186^{* *}$ & $0.134^{* *}$ \\
22 & Personal training quality & $0.204^{* *}$ & 0.078 \\
23 & Lending towels service & 0.070 & -0.017 \\
24 & Personal hygiene products in restrooms & 0.056 & -0.090 \\
25 & Medical/physiotherapist services & $0.147^{* *}$ & 0.137 \\
26 & Cafeteria/restaurant & 0.058 & 0.020 \\
27 & Wi-Fi & 0.098 & 0.044 \\
28 & Client profile in the fitness center & 0.039 & -0.013 \\
29 & Fitness center as social meeting point & 0.023 & -0.035 \\
\hline
\end{tabular}

Annotations: ${ }^{*} p<0.05 ;{ }^{* *} p<0.01$.

Table 4 shows the correlation between age and both, importance and performance values. Statistically significant correlations can be observed. The age shows a negative correlation with many importance and performance items. A significantly negative correlation is observed in performance scale, items 10 and 18. No significantly positive correlation exists. 


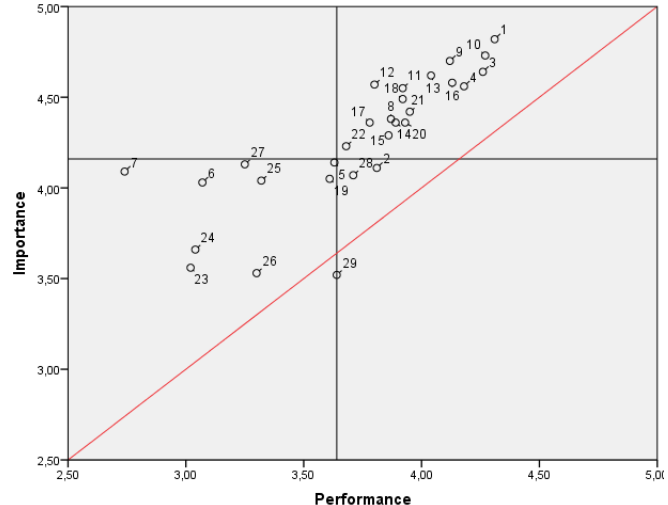

(a)

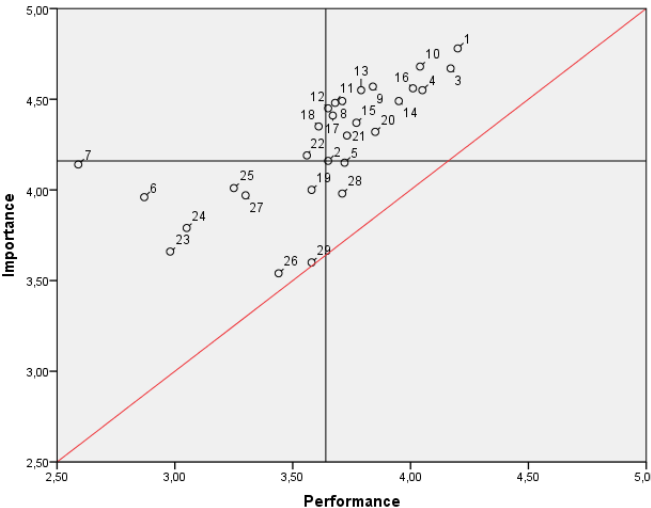

(b)

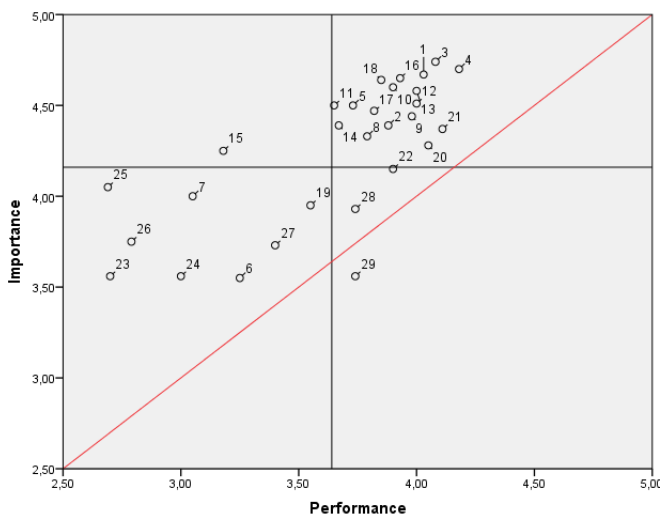

(c)

Figure 4. IPA matrix comparison by age: (a) 18 to 29; (b) 30 to 49; (c) 50 to 77.

Table 4. Age correlation with importance and performance scores.

\begin{tabular}{|c|c|c|c|}
\hline & Items & Importance & Performance \\
\hline & & Correlation with Age & Correlation with Age \\
\hline 1 & Accessibility: closeness to member homes & -0.049 & -0.050 \\
\hline 2 & Fees & 0.088 & -0.021 \\
\hline 3 & Hours and days of operation & 0.040 & -0.014 \\
\hline 4 & Kindness and treat from staff & 0.071 & 0.001 \\
\hline 5 & Achievement of outcomes from instructors & 0.085 & 0.082 \\
\hline 6 & Gifts for attracting new customers & -0.085 & -0.042 \\
\hline 7 & Gifts for rewarding current customers & 0.010 & -0.013 \\
\hline 8 & Large activity spaces & 0.045 & -0.029 \\
\hline 9 & Level of maintenance of activity spaces & -0.074 & -0.075 \\
\hline 10 & Hygiene and cleanliness of activity spaces & -0.031 & $-0.122 *$ \\
\hline 11 & Ventilation (temperature) of activity spaces & -0.032 & -0.091 \\
\hline 12 & Number of pieces of equipment & -0.040 & 0.008 \\
\hline 13 & Level of maintenance of equipment/material & -0.063 & -0.086 \\
\hline 14 & Swimming pool/SPA (general) & 0.047 & -0.041 \\
\hline 15 & Swimming pool temperature & 0.018 & -0.118 \\
\hline 16 & Spacious and hygienic restrooms & 0.014 & -0.062 \\
\hline 17 & Shower quality & 0.046 & -0.018 \\
\hline 18 & Spacious and safe lockers & -0.001 & $-0.102 *$ \\
\hline 19 & Hair dryer in restrooms & -0.012 & -0.008 \\
\hline 20 & Variety and number of activities & -0.014 & -0.003 \\
\hline 21 & Fitness service quality & -0.051 & -0.034 \\
\hline 22 & Personal training quality & -0.035 & 0.013 \\
\hline 23 & Lending towels service & 0.023 & -0.036 \\
\hline 24 & Personal hygiene products in restrooms & 0.016 & 0.018 \\
\hline 25 & Medical/physiotherapist services & 0.005 & -0.101 \\
\hline 26 & Cafeteria/restaurant & 0.034 & -0.027 \\
\hline 27 & $\mathrm{Wi}-\mathrm{Fi}$ & -0.095 & 0.023 \\
\hline 28 & Client profile in the fitness center & -0.043 & 0.012 \\
\hline 29 & Fitness center as social meeting point & 0.023 & -0.002 \\
\hline
\end{tabular}

Annotations: ${ }^{*} p<0.05$. 


\section{Discussion}

The main results show, through importance-performance analysis (IPA), different perceptions and priorities for members of fitness centers.

According to gender, the level of importance and performance is usually higher among female members. In general, men and women target the same service attributes. However, in view of the IPA and the correlational analysis, a statistically significant correlation between females and higher importance and performance values is revealed.

Firstly, female members correlate with higher levels of importance of the variety and number of activities, as well as they correlate with a better perception of that attribute's performance. The same is the case of the fitness service quality, which correlates with higher expectations among female members, but also with a better perception. These results show that the core service is essential, especially for women. These data are coherent with previous findings, regarding that preference for fitness group classes is higher among females, representing up to $74.50 \%$ of participants [35-40]. This is a significant fact, given that group training is in the third position in the worldwide fitness trends for 2020 [41].

Higher levels of importance of personal training service and kind treat from staff also correlate with the female gender. In this regard, the level of satisfaction with the achievement of outcomes thanks to instructors is better perceived by female members. Considering previous investigations on women's experiences with personal training [42], a positive experience consisting of relationships, trainer qualities, outcomes and motivation is fundamental for female members.

The level of importance of the swimming pool in general and, specifically its temperature, is directly correlated with female members. This also happens with the importance of hair dryers in restrooms, something consistent with the usual needs of each group. It is remarkable that there is evidence that women are more likely to practice recreational swimming in search of psychological well-being, whereas men focus on performance. For that reason, the swimming pool and its temperature seem to show higher values among women.

Regarding marketing strategies, women correlate with receiving gifts when joining the center. In the case of men, this is not happening to the same extent. Lastly, the importance of medical or physiotherapist services is also statistically significantly correlated with female members. Although those two last elements are not a fundamental part of the service, they should be considered by managers of fitness centers, helping them to tailor the service provided to both women and men.

Regarding IPA and correlational analysis by age, two items are statistically significantly correlated. The performance of hygiene and cleanliness of activity spaces show a significantly positive correlation with age, meaning that older people are less satisfied with the hygiene and cleanliness of those spaces. In sports services, different processes and interactions between members and the physical environment have been studied [43-45]. Members of fitness centers are increasing their expertise in the industry [7]. Although generally, the intangible aspect of fitness centers services is fundamental, some researches remark the importance of the tangible aspects, given that members are familiar with the fitness industry and the physical context around them [44].

In addition, age is also negatively correlated with the performance of spacious and safe lockers. Other researches have studied the quality of the locker service and the locker system from the point of view of managers of fitness centers [29]. Those elements are not considered priority from the managers' perspective. However, they should consider a safer environment especially when the target consumer is 50 years old or older.

\section{Conclusions}

This paper offers a useful tool for measuring the expectations and perceptions in fitness centers. Through importance-performance analysis (IPA), it was found that both women and men target the same priorities, but women give more importance to core elements of the service such as the variety and number of activities, personal training and fitness service quality. In addition, they feel more attracted by a fitness center with swimming pool and when they are provided peripheral services, 
like a welcome pack, medical or physiotherapist services. Furthermore, older members feel less satisfied with the hygiene and cleanliness of activity spaces are hygienic, as well as with the safety of lockers. Decisions regarding the quality of fitness centers services should consider this information, helping to offer a tailored experience and promoting the participation and engagement in physical activity services.

Author Contributions: Conceptualization, J.L.-Q., J.G.-U. and P.B.; Data curation, J.L.-Q., J.G.-U. and P.B.; Formal analysis, J.L.-Q., J.G.-U. and P.B.; Investigation, J.L.-Q., J.G.-U. and P.B.; Methodology, J.L.-Q., J.G.-U. and P.B.; Resources, J.L.-Q., J.G.-U. and P.B.; Supervision, J.G.-U. and P.B.; Visualization, J.L.-Q., J.G.-U. and P.B.; Writing-original draft, J.L.-Q.; Writing-review and editing, J.L.-Q., J.G.-U. and P.B. All authors have read and agreed to the published version of the manuscript.

Funding: This research received no external funding.

Acknowledgments: The authors thank to the managers for easing the access to participants of fitness centers. The present study was supported by Faculty of Sport Sciences of Universidad Europea de Madrid. J.G.-U. acknowledges "Fondo Europeo de Desarrollo Regional, Programa Operativo de la Región de Castilla-La Mancha" (2018/11744) for funding the development of his research.

Conflicts of Interest: The authors declare no conflict of interest.

\section{References}

1. IHRSA. The 2019 IHRSA Global Report; International Health; Racquet \& Sportsclub Association: Boston, MA, USA, 2019.

2. Gómez-Tafalla, A.M.; Mestre, J.A. La Importancia Del Gestor Deportivo En El Municipio; INDE: Barcelona, Spain, 2005.

3. Cheung, R.; Woo, M. Determinants of Perceived Service Quality: An Empirical Investigation of Fitness and Recreational Facilities. Contemp. Manag. Res. 2016, 12, 363-370. [CrossRef]

4. Clavel, I.; García-Unanue, J.; Iglesias-Soler, E.; Felipe, J.L.; Gallardo, L. Prediction of Abandonment in Spanish Fitness Centres. Eur. J. Sport Sci. 2018, 19, 217-224. [CrossRef] [PubMed]

5. Kruger, J.; Carlson, S.A.; Kohl, H.W. Differences in Perceived Access and Usage. Am. J. Prev. Med. 2007, 32, 500-505. [CrossRef] [PubMed]

6. Puig, N.; Heinemann, K. El Deporte En La Perspectiva Del Año 2000. Pap. Rev. Sociol. 1991, 38, 123-141. [CrossRef]

7. O'Neill, M.; Palmer, A. An exploratory study of the effects of experience on consumer perceptions of the service quality construct. Manag. Serv. Qual. Int. J. 2003, 13, 187-196. [CrossRef]

8. Lagrosen, S.; Lagrosen, Y. Exploring Service Quality in the Health and Fitness Industry. Manag. Serv. Qual. 2007, 17, 41-53. [CrossRef]

9. Alonso, D.; Rial, J.; Rial, A. Evaluación de La Calidad Percibida de Los Servicios Deportivos En El Ámbito Universitario. Revista de Psicología del Deporte 2013, 22, 143-150.

10. Calabuig, F.; Quintanilla, I.; Mundina, J. La Calidad Percibida de Los Servicios Deportivos: Diferencias Según Instalación, Género, Edad y Tipo de Usuario En Servicios Náuticos. RICYDE Revista Internacional de Ciencias del Deporte 2008, 4, 25-43. [CrossRef]

11. García-Fernández, J.; Bernal-García, A.; Lara, A.; Galán, P. La Calidad Percibida de Servicio y Su Influencia En La Fidelidad de Usuarios Mayores En Centros de Fitness Públicos. Escritos Psicol. 2013, 6, 26-34. [CrossRef]

12. Yildiz, S.M. An Importance-Performance Analysis of Fitness Center Service Quality: Empirical Results from Fitness Centers in Turkey. Afr. J. Bus. Manag. 2011, 5, 7031-7041.

13. Burillo, P.; Sánchez-Fernández, P.; Dorado, A.; Gallardo, L. Global Customer Satisfaction and Its Components in Local Sports Services. A Discrimminat Analysis. J. Sports Econ. Manag. 2012, 2, 16-33.

14. Celestino, A.; Biencinto, C. La Satisfacción Del Cliente Externo En Organizaciones de Fitness. Estudio Empírico En Centros de La Comunidad de Madrid. Eur. J. Hum. Mov. 2012, 29, 115-132.

15. Elasri, A.; Triadó, X.M.; Aparicio, P. La Satisfacción de Los Clientes de Los Centros Deportivos Municipales de Barcelona. Apunts Educación Física y Deportes 2015, 119, 109-117. [CrossRef]

16. García-Mayor, J.; Vegara-Ferri, J.M.; López-Sánchez, G.F.; Díaz-Suárez, A. Satisfacción de Usuarios de Servicios Deportivos En Orihuela (Alicante). SPORT TK-Revista EuroAmericana de Ciencias del Deporte 2016, 5, 155-162. [CrossRef] 
17. Avourdiadou, S.; Theodorakis, N.D. The Development of Loyalty among Novice and Experienced Customers of Sport and Fitness Centres. Sport Manag. Rev. 2014, 17, 419-431. [CrossRef]

18. García-Fernández, J. La Fidelidad de Clientes En Centros de Fitness Privados Españoles: La Cadena de Creación y Percepción de Valor. Ph.D. Thesis, Universidad de Sevilla, Seville, Spain, 2012.

19. Baena-Arroyo, M.J.; García-Fernández, J.; Bernal-García, A.; Lara-Bocanegra, A. Influencia Del Valor Percibido En La Fidelidad de Los Clientes de Actividades Virtuales Frente a Las Actividades Con Técnico En Centros de Fitness. Kronos 2013, 12, 65-73.

20. Bodet, G. Investigating Customer Satisfaction in a Health Club Context by an Application of the Tetraclasse Model. Eur. Sport Manag. Q. 2006, 6, 149-165. [CrossRef]

21. Clerfeuille, F.; Poubanne, Y. Differences in the Contributions of Elements of Service to Satisfaction, Commitment and Consumers' Share of Purchase: A Study from the Tetraclass Model. J. Target. Meas. Anal. Mark. 2003, 12, 66-81. [CrossRef]

22. Martilla, J.A.; James, J.C. Importance-Performance Analysis. J. Mark. 1977, 41, 77-79. [CrossRef]

23. Tarrant, M.A.; Smith, E.K. The Use of a Modified Importance-Performance Framework to Examine Visitor Satisfaction with Attributes of Outdoor Recreation Settings. Manag. Leis. 2002, 7, 69-82. [CrossRef]

24. Rial, A.; Rial, J.; Varela, J.; Real, E. An Application of Importance-Performance Analysis (IPA) to the Management of Sport Centres. Manag. Leis. 2008, 13, 179-188. [CrossRef]

25. Martínez-Caro, E.; Martínez-Caro, E.; Díaz-Suárez, A. La Calidad Del Servicio En Los Clubes de Fútbol Base de La Región de Murcia. Una Aplicación Del Análisis de Importancia-Satisfacción. SPORT TK-Revista EuroAmericana de Ciencias del Deporte 2014, 3, 33. [CrossRef]

26. Serrano-Gómez, V.; Rial, A.; Sarmento, J.P.; Carvalho, M.J. Análisis de Importancia Valoración (IPA) Como Herramienta de Diagnóstico En La Gestión de Clubes de Golf. Rev. Intercont. Gestão Desportiva 2014, 4, 86-98.

27. Arias-Ramos, M.; Serrano-Gómez, V.; García-García, O. ¿Existen Diferencias En La Calidad Percibida y Satisfacción Del Usuario Que Asiste a Un Centro Deportivo de Titularidad Privada o Pública? Un Estudio Piloto. Cuad. Psicol. Deporte 2016, 16, 99-110.

28. Zamorano-Solís, S.; García-Fernández, J. El Análisis de Importancia-Valoración Según Género y Permanencia: El Caso de Los Centros de Fitness. Materiales Para la Historia del Deporte 2018, 16, 24-35.

29. León-Quismondo, J.; García-Unanue, J.; Burillo, P. Priorities in the Management of Fitness Centers. Application of Importance-Performance Analysis. J. Sports Econ. Manag. 2018, 8, 116-136.

30. Ábalo, J.; Varela, J.; Rial, A. El Análisis de Importancia-Valoración Aplicado a La Gestión de Servicios. Psicothema 2006, 18, 730-737.

31. Bacon, D.R. A Comparison of Approaches to Importance-Performance Analysis. Int. J. Mark. Res. 2003, 45, 55-71. [CrossRef]

32. Alcaraz, N.; Soriano, C.; López, A.; Rosa, D.; Magraner, L.; Porcar, R.M.; Such, M.J.; Sánchez, J.J.; Prat, J.M. Factores de Éxito Desde La Perspectiva Del Usuario En Instalaciones Deportivas, de Ocio y Salud En Comunidad Valenciana; Instituto de Biomecánica de Valencia: Valencia, Spain, 2009.

33. Nuviala, A.; Grao-Cruces, A.; Tamayo, J.A.; Nuviala, R.; Álvarez, J.; Fernández-Martínez, A. Diseño y Análisis Del Cuestionario de Valoración de Servicios Deportivos (EPOD2). Rev. Int. Med. Cienc. Act. Física Deporte 2013, 13, 419-436.

34. Sánchez, J. Business E Fitness: El Negocio de Los Centros Deportivos; Editorial UOC: Barcelona, Spain, 2011.

35. Baena-Arroyo, M.J.; García-Fernández, J.; Gálvez-Ruiz, P.; Grimaldi-Puyana, M. Analyzing Consumer Loyalty through Service Experience and Service Convenience: Differences between Instructor Fitness Classes and Virtual Fitness Classes. Sustainability 2020, 12, 828. [CrossRef]

36. Afthinos, Y.; Theodorakis, N.D.; Nassis, P. Customers' Expectations of Service in Greek Fitness Centers. Gender, Age, Type of Sport Center, and Motivation Differences. Manag. Serv. Qual. 2005, 15, 245-258. [CrossRef]

37. Baena-Arroyo, M.J.; García-Fernández, J.; Bernal-García, A.; Lara-Bocanegra, A.; Gálvez-Ruiz, P. El Valor Percibido y La Satisfacción Del Cliente En Actividades Dirigidas Virtuales y Con Técnico En Centros de Fitness. Rev. Psicol. Deporte 2016, 25, 219-227.

38. Águila, C.; Sicilia, A.; Muyor, J.M.; Orta, A. Cultura Posmoderna y Perfiles de Práctica En Los Centros Deportivos Municipales. Rev. Int. Med. Ciencias Act. Fis. Deporte 2009, 9, 81-95.

39. Escamilla-Fajardo, P.; Núñez-Pomar, J.M. Satisfacción y Valor Percibido En Un Servicio Deportivo Público: Una Propuesta de Análisis y Acciones de Gestión. J. Sport. Econ. Manag. 2014, 4, 4-21. 
40. Pérez-Villalba, M.; García-Fernández, J.; Gómez-Chacón, R.; Fernández-Martínez, N. Las Actividades Dirigidas En Centros Deportivos y Su Valor Como Elemento de Fidelización. Sport TK Rev. Euroam. Ciencias Deporte 2018, 7, 17-26. [CrossRef]

41. Thompson, W.R. Worldwide Survey of Fitness Trends for 2020. ACSMs Heal. Fit. J. 2019, 23, 10-18.

42. Madeson, M.N.; Hultquist, C.N.; Church, A.; Fisher, L.A. A Phenomenological Investigation of Women's Experiences With Personal Training. Int. J. Exerc. Sci. 2010, 3, 157-169.

43. Cunningham, L.F.; Young, C.E.; Lee, M. A Customer-Based Taxonomy of Services: Implications for Service Marketers. Adv. Serv. Mark. Manag. 1997, 6, 189-202.

44. Mañas-Rodríguez, M.Á.; Giménez-Guerrero, G.; Muyor-Rodríguez, J.M.; Martínez-Tur, V.; Moliner-Cantos, C.P. Los Tangibles Como Predictores de La Satisfacción Del Usuario En Servicios Deportivos. Psicothema 2008, 20, 243-248.

45. Martínez-Tur, V.; Peiró, J.M.; Ramos, J. Linking Situational Constraints to Customer Satisfaction in a Service Environment. Appl. Psychol. Int. Rev. 2005, 54, 25-36. [CrossRef]

(C) 2020 by the authors. Licensee MDPI, Basel, Switzerland. This article is an open access article distributed under the terms and conditions of the Creative Commons Attribution (CC BY) license (http://creativecommons.org/licenses/by/4.0/). 